\title{
SUMMER FLOCKS OF SANDHILL CRANES IN MANITOBA
}

\section{PETER TAYLOR, P.O. Box 597, Pinawa, MB R0E 1 Lo}

Sandhill Cranes form large flocks during migration and in winter, but summer flocks are apparently unusual. $^{1}$ This note describes several observations of summer flocks in Manitoba; localities are shown in Figure 1. Koonz reported a flock of Sandhill Cranes in a recently germinated grain field near Waterhen on 14-15 June $1989 .^{1}$ At least 112 adult cranes, which Koonz suggested were non-breeders, congregated in the field during the evening on the latter date.

In the late morning of 1 July 1993, I counted 108 Sandhill Cranes in a field of seedling grain (about $20 \mathrm{~cm}$ tall) and adjoining weedy canola, 35 $\mathrm{km}$ east of Ashern. In the early afternoon of the following day, I saw 64 Sandhill Cranes, again in a field of young cereal plants, south of the junction of provincial roads 282 and 283 (southwest of The Pas).

On 15 June 1981, I saw 45 Sandhill Cranes in a seedling grain field 5 $\mathrm{km}$ south-southeast of River Hills. Three days later, Dennis Fast and Harvey Lane accompanied me to the field and we counted 95 birds at 8 p.m. A visit at 8:30 p.m. on 26 June 1981 , however, turned up only a few cranes. On 17 June 1990, I counted 70 Sandhill Cranes in seedling grain in the same area.

In summer 1992, a flock of Sandhill Cranes frequented canola fields along provincial road $317,4 \mathrm{~km}$ northwest of Lac du Bonnet. When discovered at 10:00 a.m., 27 June 1992, 76 birds were seen. Later counts were $60+$ at 1 p.m., 1 July; 45 at 8 p.m., July 10; 84 at 7:50 p.m., 14 July; 52 at 1:15 p.m., 16 July; 20 at 7:30 p.m., 22 July; and 24 on 25 July. By late July, the canola was almost tall enough to hide the cranes. None was seen at 7 p.m. on 5 August.

It is not unusual to see flocks of Sandhill Cranes in farmland in southeastern Manitoba in August; these could be either local summering birds, pre-migratory concentrations, or early migrants.

Based on these observations, summer flocks of Sandhill Cranes appear to occur regularly in southern and central Manitoba. They tend to gather in fields of seedling crops, such as cereal grains and canola, often in the evening. The population of Sandhill Cranes in this region has increased in recent years, so the lack of similar records before 1981 is not surprising. As suggested by Koonz, these are probably gatherings of non-breeding birds. Tacha cites a breeding age of three to five years for this species. ${ }^{2}$ Therefore, a substantial non-breeding subadult population might be expected in or near nesting areas, although nonbreeding flocks do not necessarily originate from local populations. The five localities (Figure 1) follow a diagonal line across the province, illustrating the Sandhill Crane's affinity for farmland near the margins of the boreal forest.

There are few definite breeding records of Sandhill Cranes in southeastern Manitoba, but bugling and dancing pairs are often seen in spring. They appear to breed in 


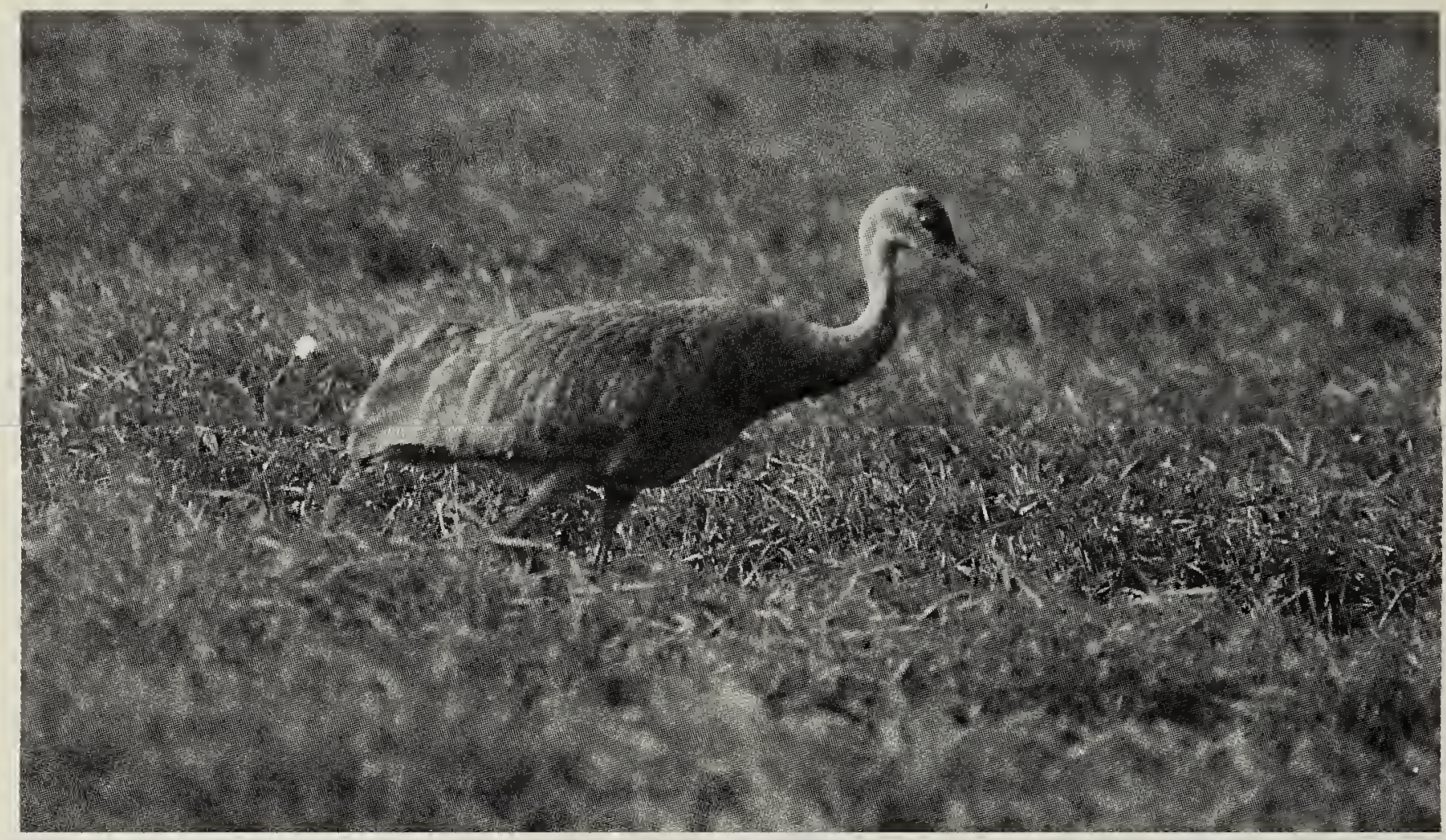

Roy John

secluded bogs. On 18 June 1989, Colin Bradshaw (a visiting birder from England) reported being "attacked" by a Sandhill Crane, evi-

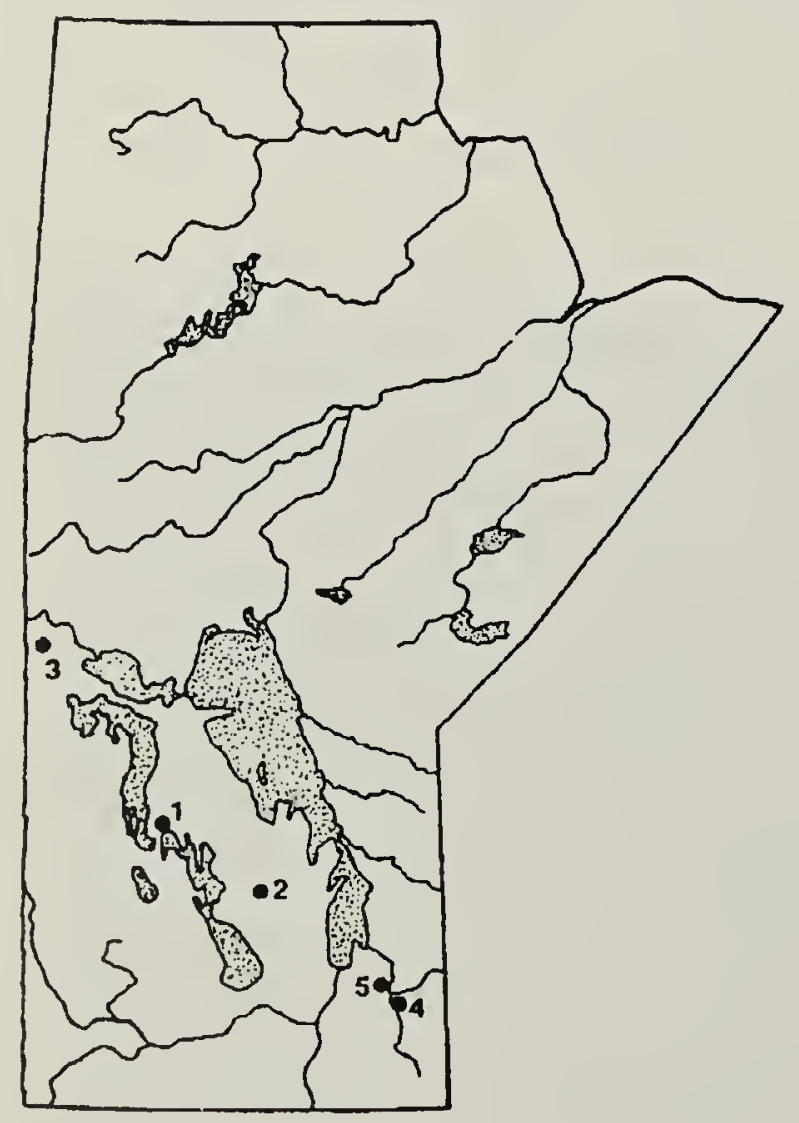

Figure 1. Map of Manitoba, showing the localities discussed in the text, near (1) Waterhen, (2) Ashern, (3) The Pas, (4) River Hills, and (5) Lac du Bonnet. dently protecting a nest or young, in an extensive bog about $20 \mathrm{~km}$ southwest of Lac du Bonnet. On 16 June 1996, a party of birders led by David Hatch saw a pair of Sandhill Cranes with two small young in an alfalfa field $2 \mathrm{~km}$ south of Lac du Bonnet. These dates indicate that breeding cranes would be attending closely to nesting activities when most of the flocks described above were seen.

Tacha found that cheek-patch colour in Sandhill Cranes changes with age (white in adults; gray in $100 \%$ of 17 1.5-to-2-year-old birds and 78\% of 18 2.5-to-3-year-olds). ${ }^{2}$ When observing the Lac du Bonnet flock on 1 July 1992, I noted that the white cheek patch was clearly visible on most birds, although a little dingy in many cases. This observation is inconclusive, but would be consistent with a flock composed mainly of birds at least three years old.

1. Koonz, W.H. 1990. Unusual concentrations of Sandhill Cranes during the breeding season. Blue Jay 48:157.

2. Tacha, T.C. 1988. Social organization of Sandhill Cranes from midcontinental North America. Wildlife Monographs No. 99, The Wildlife Society, Bethesda, MD. 37 pp. 